\title{
Efficiency of two inoculation methods of Pseudomonas putida on growth and yield of tomato plants
}

\author{
Luis G. Hernández-Montiel ${ }^{1}$, César J. Chiquito-Contreras ${ }^{2}$, Bernardo Murillo-Amador ${ }^{1}$, \\ Librado Vidal-Hernández², Evangelina E. Quiñones-Aguilar ${ }^{3}$, and Roberto G. Chiquito- \\ Contreras $^{2 *}$
}

${ }^{1}$ Centro de Investigaciones Biológicas del Noroeste, La Paz, Baja California Sur, 23096, México. ${ }^{2}$ Facultad de Ciencias Agrícolas, Campus Xalapa, Universidad Veracruzana, Xalapa, Veracruz, 91090, México. ${ }^{3}$ Centro de Investigación y Asistencia en Tecnología y Diseño del Estado de Jalisco, Guadalajara, Jalisco, 44270, México. ${ }^{*}$ Corresponding author: rchiquito@uv.mx

\begin{abstract}
The objective of this study was to determine the efficiency of applying microcapsules and liquid inoculation of three Pseudomonas putida strains on growth and yield of tomato plants in greenhouse where the results showed differences between both treatments. Rhizobacterial strains FA-8, FA-56, and FA-60 of P. putida, were assessed individually and combined to determine their capacity to produce indoleacetic acid (IAA). The three strains demonstrated the capacity to produce IAA in vitro, of which FA-56 stood out with $23.02 \mu \mathrm{g} \mathrm{mL}^{-1}$ in the microcapsule treatment with significant increases in plant height, stem diameter, radical volume, dry biomass, fruit yield, and rhizobacterial population (CFU). These responses could have been associated to the intrinsic capacity of this strain to produce a greater amount of IAA, hormone related to promoting plant growth. The use of plant growth-promoting rhizobacteria (PGPR) as biofertilizers by means of microcapsules could be an alternative in agricultural management and sustainable production of tomato. Immobilization of $P$. putida rhizobacteria by alginate microcapsules confers protection and gradual release, improving adhesion, permanency, and colonization of cells on the roots, promoting a better effect as PGPR and productivity in tomato plants.
\end{abstract}

Keywords: Alginate microcapsules, indoleacetic acid, rhizobacteria, PGPR, Lycopersicon esculentum 


\section{Introduction}

The use of microorganisms as biofertilizers in cultivation production has been a common practice in the last years. Plant growth-promoting rhizobacteria (PGPR) (Kloepper, 1993) has stood out as biofertilizer because these microorganisms adapt and grow rapidly around plant roots (Ahirwar et al., 2015; Ul Hassan and Bano, 2015). Moreover, PGPR induce growth directly or indirectly by producing regulators, such as gibberellins, cytokinins and auxins, fixation of atmospheric nitrogen, insoluble phosphorous solubilization (Lugtenberg and Kamilova, 2009; Belimov et al., 2015), siderophore production (carboxylates, hydroxamates, phenol catechol, and pyroverdines) (Solanki et al., 2014; Barea, 2015), antibiotics, extracellular anti-fungal metabolites, such as proteases, glucanases, chitinases, salicylic acid, cyanide (Bakker et al., 2013; Kamou et al., 2015), and systemic resistance mechanisms of the host (Bakker et al., 2013). The genera of PGPR that mostly stand out are Pseudomonas, Azospirillum, Azotobacter, Enterobacter, Bacillus, Rhizobium, among others (Berg, 2009; Barea, 2015; Kamou et al., 2015), which can be inoculated in plant, seed, root, or soil (Shen et al., 2013; Bashan et al., 2014). Plant response to PGPR inoculation varies considerably depending on rhizobacterial species, host, soil type, inoculum density, environmental conditions, and inoculation method (Berg, 2009; Shah et al., 2017). The method of incorporating PGPR has an influence on the establishment and permanency of bacterial populations in the rhizosphere and indirectly on its growth promoter effects (Sivakumar et al., 2014; He et al., 2016). Within its inoculation forms in plants, those that stand out are microcapsules, which have demonstrated to be more efficient than liquid inoculation because they mainly provide protection to bacterial cells allowing them to survive longer in the plant rhizosphere (Bashan et al., 2014; Schoebitz and
Belchí, 2016). Nonetheless, inconsistencies have been found in the results that have been reported because some studies have mentioned that plant increase in seed germination, plant growth, biomass, and yield were not significantly differently when PGPR were inoculated in microcapsule or in liquid forms in plant roots (Sivakumar et al., 2014; Schoebitz and Belchí, 2016).

For this reason, it was necessary to evaluate the effects of different inoculation techniques of each rhizobacterial strain to find the most efficient method for promoting plant growth and yield (Atieno et al., 2012; He et al., 2016). Thus, the objective of this study was to determine the efficiency of applying microcapsules and liquid inoculation of three Pseudomonas putida strains on growth and yield of tomato plants in a greenhouse experiment.

\section{Materials and Methods}

\subsection{Study site}

The experiment was conducted in a $160-\mathrm{m}^{2}$ tunneltype greenhouse located in the Faculty of Agricultural Sciences Campus Xalapa, Universidad Veracruzana, Xalapa, Veracruz, Mexico at latitude $19^{\circ} 30^{\prime} \mathrm{N}, 96^{\circ}$ $55^{\prime} \mathrm{W}$ and altitude $1450 \mathrm{~m}$.

\subsection{Pseudomonas putida strains}

Strains of $P$. putida were provided by the Laboratory of Agricultural Chemistry of the Faculty of Agricultural Sciences, Campus Xalapa, Universidad Veracruzana catalogued as FA-8 (NCBI GenBank database sequence with accession number KT223583); FA-56 (NCBI GenBank database sequence with accession number KT223581); and FA-60 (NCBI GenBank database sequence with accession number KT223582). 
Rhizobacteria were grown in B-King (glycerol $10 \mathrm{ml}$ $\mathrm{L}^{-1}$, peptone $15 \mathrm{~g} \mathrm{~L}^{-1}$, magnesium sulfate $1.0 \mathrm{M}[1 \mathrm{ml}$ $\mathrm{L}^{-1}$ and dibasic potassium phosphate $1.5 \mathrm{~g} \mathrm{~L}^{-1}$ ) liquid medium at $28 \pm 2{ }^{\circ} \mathrm{C}$ and $160 \mathrm{rpm}$ for $48 \mathrm{~h}$. The concentration of each rhizobacterial strain was adjusted to $10^{9}$ cells $\mathrm{ml}^{-1}$ with a spectrophotometer at a wavelength of $660 \mathrm{~nm}$ and absorbance of 1.

\subsection{Determination of indoleacetic acid}

Rhizobacteria were grown in $20 \mathrm{ml}$ of B-King liquid medium supplemented with $0.5 \mathrm{~g} \mathrm{~L}^{-1}$ of L-tryptophan and incubated at $28 \pm 2{ }^{\circ} \mathrm{C}$ and $160 \mathrm{rpm}$ for $72 \mathrm{~h}$. Rhizobacterial cultures were centrifuged at $5000 \mathrm{rpm}$ for $15 \mathrm{~min}$ and one $\mathrm{ml}$ of the supernatant was mixed in two $\mathrm{ml}$ of Salkowski's reagent $\left(\mathrm{FeCl}_{3} 12 \mathrm{~g} \mathrm{~L}^{-1}\right.$ in $\mathrm{H}_{2} \mathrm{SO}_{4} 7.9 \mathrm{M}$ ), letting it stand at room temperature and complete darkness for $30 \mathrm{~min}$ (Glickmann and Dessaux,1995). The indoleacetic acid (IAA) of each sample was quantified with a spectrophotometer at a wavelength of $530 \mathrm{~nm}$. The production of IAA of each rhizobacterial strain was determined by a standard curve of $0,5,10,15,20,25,30,35,40 \mu \mathrm{g} \mathrm{ml}^{-1}$ of pure IAA, considering B-King medium without inoculating as control. Three replicates per treatment were performed, and the experiment was conducted twice.

\subsection{Production of tomato seedlings}

Seeds of Monica (SAKATA ${ }^{\circledR}$ Seed Corporation, Yokohama, Japon) hybrid saladette tomato were used. For seedling production, a 200-cavity polystyrene germination tray was used, previously disinfected with 3\% sodium hypochlorite solution for $5 \mathrm{~min}$ and washed-rinsed with sterile distilled water. The germination tray was filled with a mixture based on vermicompost, pumice, and sand $(2: 1: 1 \mathrm{v} / \mathrm{v})$, which was sterilized with a sanitizing and disinfecting liquid solution of Anibac $580^{\circledR}$ (Promotora Técnica Industrial,
S.A. de C.V., México, e.g. quaternary ammonium [1st. generation] at $8.6 \%$ and quaternary ammonium [double chain] at 3.7\%) in doses of $5 \mathrm{ml} \mathrm{L}^{-1}$. One seed per cavity was placed in the germination tray and maintained in greenhouse at $26 \pm 5{ }^{\circ} \mathrm{C}$ and $60 \pm 5 \%$ RH for 30 days.

\subsection{Inoculation methods of Pseudomonas putida}

Method 1: To produce sodium alginate microcapsules, $100 \mathrm{ml}$ of each rhizobacterial concentration were taken and mixed with $2.2 \mathrm{~g}$ of sodium alginate and shaken at $350 \mathrm{rpm}$ for $20 \mathrm{~min}$. A 5-ml transparent polyethylene Pasteur pipette was used to take the rhizobacterial mixture of sodium alginate forming drops placed in a sterile solution of $0.1 \mathrm{M} \mathrm{CaCl}_{2}$ at $0.1 \mathrm{M}$. The solution was shaken at $100 \mathrm{rpm}$ for $30 \mathrm{~min}$; microcapsules were withdrawn and washed three times with sterile saline solution of $\mathrm{NaCl}$ at $0.85 \%(w / v)$. A batch of microcapsules $\left(\mathrm{MIX}_{\mathrm{mc}}\right.$ ) was made with the mixture of the three rhizobacteria. Microcapsules of approximately four $\mathrm{mm}$ in diameter were preserved in a sterile solution of $0.1 \mathrm{M} \mathrm{CaCl}_{2}$ at room temperature for $24 \mathrm{~h}$ until their inoculation in plants.

Method 2: At transplanting, the root of each plant was inoculated with $5 \mathrm{ml}$ of each rhizobacterial strain grown in B-King liquid medium (concentration $10^{9}$ cells $\mathrm{ml}^{-1}$ ). A batch of seedlings named $\mathrm{MIX}_{\mathrm{lm}}$ was inoculated at the same time with the mixture of the three rhizobacteria strains.

\subsection{Transplant and inoculation of Pseudomonas pu- tida}

Previous to transplanting, seedling roots were washed; subsequently, 50 microcapsules (mc) of sodium alginate of each rhizobacterial were applied to a group of seedlings, and $5 \mathrm{ml}$ of liquid medium ( $\mathrm{lm}$ ) of each rhizobacterial strain were applied to another group. For both inoculation methods, a group of seedlings was 
inoculated with the combination of the three rhizobacterial strains named MIX. A randomized block design was used with nine treatments: FA- $8_{\text {mc }}$, FA- $56_{\text {mc }}$, FA$60_{\mathrm{mc}}$, MIX $_{\mathrm{mc}}, \mathrm{FA}-8_{\mathrm{lm}}, \mathrm{FA}-56_{\mathrm{lm}}, \mathrm{FA}-60_{\mathrm{lm}}$, MIX $_{\mathrm{lm}}$, and control (plants without rhizobacterial). The plants were maintained in greenhouse in 8 - $\mathrm{kg}$ black polyethylene bags containing as substrate $6 \mathrm{~kg}$ of pumice previously disinfected with liquid solution of Anibac $580^{\circledR}$ (in doses of $5 \mathrm{ml} \mathrm{L}^{-1}$ ) for 120 days. During the experiment, an average temperature of $26 \pm 5^{\circ} \mathrm{C}$ and $60 \pm 5 \% \mathrm{RH}$ was recorded. All plants in all treatments were fertilized with a nutritional solution $\left(\mathrm{g} \mathrm{L}^{-1}\right)$ composed of $\mathrm{Ca}\left(\mathrm{NO}_{3}\right)_{2} \cdot 4 \mathrm{H}_{2} \mathrm{O}(1.43), \mathrm{Mg}\left(\mathrm{NO}_{3}\right)_{2}(0.95), \mathrm{KNO}_{3}(0.38)$, $\mathrm{KH}_{2} \mathrm{PO}_{4}(0.35)$ and micronutrients TRADECORP ${ }^{\circledR} \mathrm{AZ}$ (Madrid, España) $\mathrm{Fe}, \mathrm{Zn}, \mathrm{Mg}, \mathrm{B}, \mathrm{Cu}$, and $\mathrm{Mo} \mathrm{(0.03).}$ At the end of the experiment, height, stem diameter, radical volume, root length, fresh and dry biomass, fruit yield, total soluble solids ( ${ }^{\circ}$ Brix) in ripe fruit juice, and colony forming units (CFU) were quantified. Eight replicates were performed per treatment, and the experiment was conducted twice.

\subsection{Rhizobacterial population in root}

Determinations of CFU were made at the end of the experiment (120 days after inoculation). One sample of $3-\mathrm{g}$ fresh root was collected from the inoculated plants with each rhizobacterial strain and the noninoculated control. The samples were placed in Petri dishes with sterile saline solution of $\mathrm{NaCl}$ at $0.85 \%$ $(\mathrm{w} / \mathrm{v})$. Subsequently, following the methodology proposed by Holguin and Bashan (1996), samples were macerated with a sterile glass rod, and serial dilutions were performed by triplicate per treatment for plate counting with solid B-King culture medium. After incubation at $28 \pm 2{ }^{\circ} \mathrm{C}$ for $72 \mathrm{~h}$, the population of each rhizobacterial strain was determined and expressed as CFU $10^{8} \mathrm{~g}^{-1}$ (Gamalero et al., 2002). The experiment was conducted twice.

\subsection{Statistical analyses}

The laboratory experiments (IAA and CFU) were conducted in a completely randomized design, and the greenhouse experiment was established with randomized block design. The data obtained in the experiments were processed by the analysis of variance (ANOVA) and Duncan's multiple range test (P $<0.05$ ) with the statistical program SAS version 9.4 for Windows.

\section{Results}

\subsection{Production of indoleacetic acid}

The production of IAA of the three $P$. putida rhizobacteria showed significant differences $(\mathrm{P}<0.05)$ with variations from 13.92 to $23.02 \mu \mathrm{g} \mathrm{mL}^{-1}$ (Figure 1). The metabolic activity of strain FA-56 stood out producing the greatest concentration of auxin, which influenced an increase in growth promotion and yield of tomato plants (Table 1).

\subsection{Effect of two inoculations methods of Pseudomo- nas putida on tomato plant growth and productivity}

The plants inoculated with microcapsules or liquid bacterial culture of the three rhizobacteria showed significant differences $(\mathrm{P}<0.05)$ on morphological parameter and productivity of tomato (Table 1). The plants inoculated with microcapsules of the strain FA-56 increased height, stem diameter, radical volume, dry biomass, and fruit yield in 13\%, 31\%, 22\%, $45 \%$, and $20 \%$, respectively. The MIX $_{\mathrm{mc}}$ treatment increased $34 \%$ root length, and the MIX $_{\operatorname{lm}}$ treatment increased $72 \%$ fresh biomass. For the variables, radical volume and total soluble solids ( ${ }^{\circ}$ Brix) did not show statistically significant differences among the treatments. 


\subsection{Rhizobacterial population}

The presence of the rhizobacterial population (CFU) quantified in the rhizosphere of the plants inoculated with microcapsules and liquid bacterial culture with P. putida strains showed significant differences
$(\mathrm{P}<0.05)$ among treatments (Figure 2). With the microcapsules, a greater CFU was maintained for all the rhizobacteria (CFU $10^{8} \mathrm{~g}^{-1}$ of roots), of which the population obtained from the strain FA-56 stood out. A low population of bacteria was observed in the control treatment.

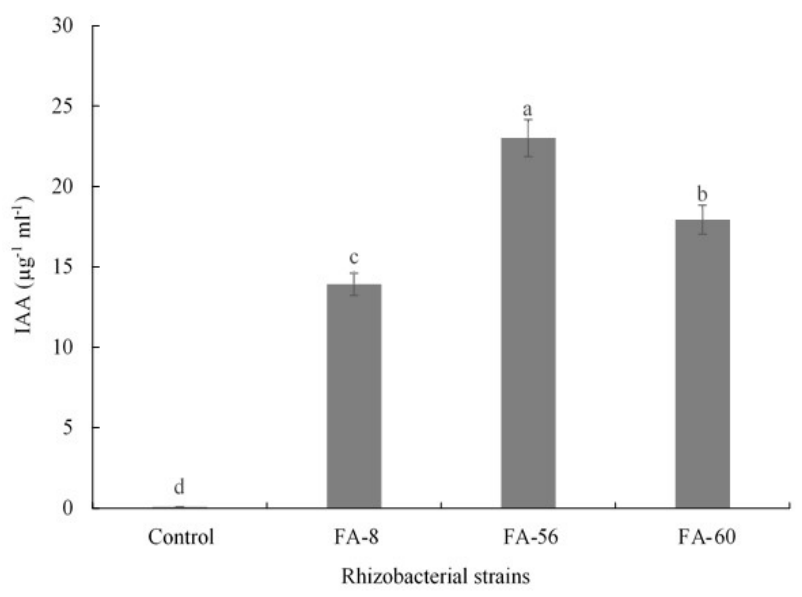

Figure 1. Bacterial indoleacetic acid (IAA) produced in vitro by strains FA-8, FA-56, FA-60 of Pseudomonas putida and control (B-King liquid medium without inoculation). Each value of data represents the average of three replicates. Different letters show significant differences under Duncan's multiple range test $(\mathrm{P}<0.05)$.

Table 1. Effect of microcapsules and liquid medium bacterial of three rhizobacteria strains of Pseudomonas putida on growth and productivity of tomato plants in greenhouse.

\begin{tabular}{|c|c|c|c|c|c|c|c|c|}
\hline & $\begin{array}{l}\text { Height } \\
(\mathrm{cm})\end{array}$ & $\begin{array}{c}\text { Stem } \\
\text { diameter } \\
(\mathrm{mm})\end{array}$ & $\begin{array}{c}\text { Root } \\
\text { length } \\
(\mathrm{cm})\end{array}$ & $\begin{array}{c}\text { Radical } \\
\text { volume } \\
\left(\mathrm{cm}^{3}\right)\end{array}$ & $\begin{array}{c}\text { Fresh } \\
\text { biomass } \\
(\mathrm{g})\end{array}$ & $\begin{array}{c}\text { Dry } \\
\text { biomass } \\
\text { (g) }\end{array}$ & $\begin{array}{c}\text { Fruit yield } \\
\text { (g) }\end{array}$ & $\begin{array}{c}\text { Total } \\
\text { soluble } \\
\text { solids }\end{array}$ \\
\hline Treatments & & & & & & & & $\begin{array}{l}{ }^{\circ} \text { Brix } \\
(\%)\end{array}$ \\
\hline Strain FA- 8 mc $^{*}$ & $96.50^{\mathrm{ab}}$ & $8.19^{\mathrm{bc}}$ & $55.63^{\mathrm{bc}}$ & $64.50^{\mathrm{a}}$ & $320.51^{\text {bcd }}$ & $54.65^{\text {bcde }}$ & $786.35^{\mathrm{cb}}$ & $5^{\mathrm{a}}$ \\
\hline Strain FA-56 $6_{\mathrm{mc}}$ & $100.88^{\mathrm{a}}$ & $9.40^{\mathrm{a}}$ & $62.37^{\mathrm{ab}}$ & $70.25^{\mathrm{a}}$ & $411.13^{\mathrm{ab}}$ & $72.63^{\mathrm{a}}$ & $944.13^{\mathrm{a}}$ & $5^{\mathrm{a}}$ \\
\hline Strain FA- $60_{\mathrm{mc}}$ & $93.38^{\mathrm{ab}}$ & $7.80^{\mathrm{bcd}}$ & $55.87^{\mathrm{bc}}$ & $66.12^{\mathrm{a}}$ & $350.38^{\mathrm{abc}}$ & $57.70^{\text {abcde }}$ & $816.88^{\mathrm{ab}}$ & $5.5^{\mathrm{a}}$ \\
\hline $\mathrm{MIX}_{\mathrm{mc}} \dagger$ & $89.10^{\mathrm{b}}$ & $7.96^{\mathrm{bcd}}$ & $67.38^{\mathrm{a}}$ & $66.37^{\mathrm{a}}$ & $365.55^{\mathrm{abc}}$ & $68.15^{\mathrm{abc}}$ & $878.89^{\mathrm{ab}}$ & $5^{\mathrm{a}}$ \\
\hline Strain FA- $8 \operatorname{lm} \ddagger$ & $92.25^{\mathrm{ab}}$ & $7.29^{\mathrm{cd}}$ & $52.50^{\mathrm{bc}}$ & $54.30^{\mathrm{a}}$ & $309.00^{\mathrm{cd}}$ & $52.82^{\text {cde }}$ & $665.68^{\mathrm{c}}$ & $5^{\mathrm{a}}$ \\
\hline Strain FA-56 $1 \mathrm{~lm}$ & $98.13^{\mathrm{ab}}$ & $8.46^{\mathrm{b}}$ & $56.62^{\mathrm{abc}}$ & $66.25^{\mathrm{a}}$ & $362.75^{\mathrm{abc}}$ & $67.10^{\mathrm{abcd}}$ & $843.40^{\mathrm{ab}}$ & $5.5^{\mathrm{a}}$ \\
\hline Strain FA-60 $1 \mathrm{~lm}$ & $91.17^{\mathrm{ab}}$ & $7.93^{\text {bcd }}$ & $56.75^{\mathrm{abc}}$ & $62.63^{\mathrm{a}}$ & $248.70^{\mathrm{d}}$ & $47.63^{\mathrm{e}}$ & $809.35^{\mathrm{abc}}$ & $5^{\mathrm{a}}$ \\
\hline $\mathrm{MIX}_{\mathrm{Im}}$ & $92.25^{\mathrm{ab}}$ & $7.53^{\mathrm{cd}}$ & $57.63^{\mathrm{abc}}$ & $59.38^{\mathrm{a}}$ & $442.63^{\mathrm{a}}$ & $70.50^{\mathrm{ab}}$ & $829.80^{\mathrm{ab}}$ & $5.5^{\mathrm{a}}$ \\
\hline Control & $88.80^{\mathrm{b}}$ & $7.15^{\mathrm{d}}$ & $50.25^{\mathrm{c}}$ & $57.50^{\mathrm{a}}$ & $256.90^{\mathrm{d}}$ & $49.86^{\mathrm{de}}$ & $782.38^{\mathrm{bc}}$ & $5^{\mathrm{a}}$ \\
\hline
\end{tabular}

*Alginate microcapsules $(\mathrm{mc}) \dagger \mathrm{MIX}=$ mixture of three rhizobacterial strains of $P$. putida. $\$$ liquid medium bacterial $(\mathrm{lm})$. Average values $(n=8)$ within the same column with different letters denote significant differences in the assay with randomized block design and Duncan's multiple range test $(\mathrm{P}<0.05)$. 


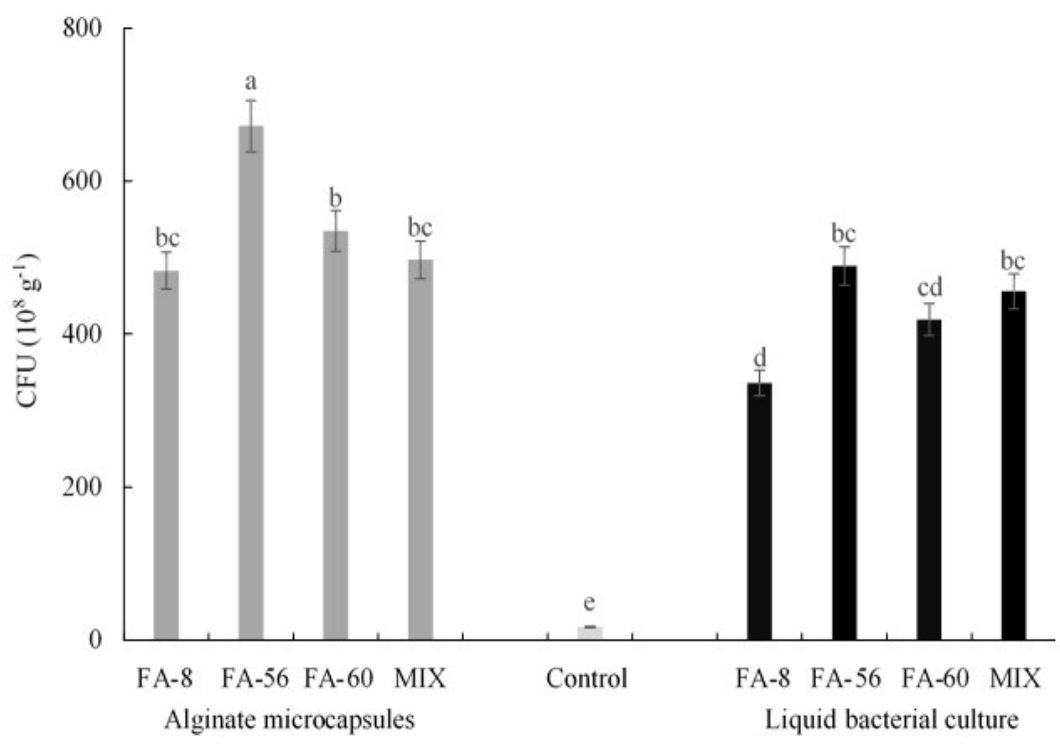

Figure 2. Colony forming units (CFU) quantified in "Monica" hybrid tomato plant roots, inoculated with microcapsules and liquid medium bacterial of Pseudomonas putida strains FA-8, FA-56, FA-60, MIX (mixture of three strains) and control (plants without rhizobacteria) at 120 days after transplanted to greenhouse. Each value of data represents the average of three replicates. Different letters show significant differences under Duncan's multiple range test $(\mathrm{P}<0.05)$.

\section{Discussion}

The production of IAA has been widely studied as plant growth-promoting mechanism by rhizobacteria, stimulating cell division and tissue, differentiation directly expressed in biomass increase (Viscardi et al., 2016; Nadeem et al., 2016) besides intervening in enzymatic activities as ACC deaminase related with ethylene levels and reducing sugar during fruit maturation (Belimov et al., 2015; Gamalero and Glick, 2015). Determining IAA in rhizobacteria as a growth-promoting mechanism and an increase in cultivation productivity is important within the species selection process, such as $P$. fluorescens and $P$. putida (Ahirwar et al., 2015; Shah et al., 2017).

Inoculating microcapsules of rhizobacteria on plants increased growth and yield of tomato because this type of inoculation improves the effect of PGPR, acting as mini-reactors that confer stability, protection, population increase, and a gradual liberation of bacterial cells in the plant rhizosphere environment (Sivakumar et al., 2014; Schoebitz and Belchí, 2016). Different authors have mentioned a greater effect in applying rhizobacteria based on microcapsules compared with its liquid application, increasing diverse morphological parameters and productivity in tomato (Pastor et al., 2016), corn (Hungria et al., 2010) and potato (Arseneault et al., 2015), among others. The stimulating activity of plant growth by rhizobacteria as $P$. putida is due to its capacity of synthesizing growth regulators, such as auxins, gibberellins, cytokinins, and vitamins; antagonistic metabolites as siderophores and 
hydrocyanic acid ( $\mathrm{HCN})$, as well as for their ability to facilitate nutrients through phosphorus solubilization, biological fixation of atmospheric nitrogen, and ion chelation (Vacheron et al., 2013; Bashan et al., 2014; U1 Hassan and Bano, 2015). The highest content of total soluble solids ( $\left.{ }^{\circ} \mathrm{Brix}\right)$ in fruits of the three treatments $\left(\mathrm{FA}-60_{\mathrm{mc}}, \mathrm{FA}-56_{\mathrm{lm}}\right.$ and $\mathrm{MIX}_{\mathrm{lm}}$ ) was likely due to metabolism of rhizobacteria that stimulated plant growth and essential nutrient assimilation. It induced ethylene production (Gamalero and Glick, 2015), which promoted enzyme synthesis reducing sugar in the fruit cell wall and generating simple sugar that increased total soluble solids ( ${ }^{\circ}$ Brix) in fruit during the maturity process (Ordookhani and Zare, 2011; Vázquez-Ovando et al., 2012).

Although the three strains assessed as growth promoters were from the same $P$. putida species, the fact that strain FA-56 stood out in most of the morphological parameters and fruit yield of tomato. This result could have been due to a more efficient metabolic activity of the strain since its capacity to synthesize IAA was greater than the other strains (FA-8 and FA-60). This growth regulator produced by rhizobacteria has been closely related to its direct effect for promoting plant growth, as it has been reported in some studies (Joshi and Joshi, 2017; Nadeem et al., 2016; Zerrouk et al., 2016).

To influence plant growth rapidly and directly, rhizobacteria express chemotactic mechanisms, related to the presence of chemoreceptors and genetically codified systems. These factors determine the ability of rhizobacteria to colonize the rhizosphere rapidly and efficiently establishing communication with root cells, which cause rhizobacterial movement to the plant rhizoplane initiating a mutually beneficial relationship (Berg, 2009; Mwita et al., 2016; Israr et al., 2016).

Combining the three P. putida, rhizobacteria did not have a synergic effect among them, which is why plant growth promotion was less than when it was individually induced by the FA-56 strain in microcap- sules although the three strains showed the capacity to synthesize IAA. Studies have shown that the incapacity of several microorganisms to act jointly as effective inoculants in plant growth promotion is related to the root colonization process since bacterial cells grow and distribute through the rhizosphere depending on soil humidity, $\mathrm{pH}$, temperature, microbial antagonism, space competence, radical exudates, as well as the physiological state in which the bacterium introduces itself and the likely specificity of the host. Facing these factors, only those cells capable of proliferating rapidly and invading the roots in a large number will achieve promoting plant growth effectively (Gupta et al., 2015; Pathak et al., 2017; Vejan et al., 2016).

The population rate of bacterial cells in plant rhizosphere depends essentially on the inoculation method applied and in the organic compounds produced by the radial exudates, of which aminoacids, organic acids, phenols, phytohormones (auxins, gibberellins, and cytokinins), sugar, vitamins, and enzymes stand out (Berg, 2009; Bashan et al., 2014; Barea, 2015). The quantity and quality of plant radical exudates promote competence for these metabolites in rhizobacteria, as well as by the site they occupy on the plant root; thus, the unions between the epidermic cells and the area where the root emerges are the sites with greater attraction, adhesion, activity, and microbial population (Raaijmakers et al., 2009; Vacheron et al., 2013). With respect to the low bacterial population density observed in the control treatment where the plants were not inoculated with $P$. putida rhizobacterial strains, it could have been due to the presence of bacteria or yeast coming from contaminated sources, such as irrigation water, plant management during pruning, pest and disease control, and harvest, among others. Nonetheless, such population did not affect plant growth in control.

Finally, immobilization of bacterial cells by microcapsules offers greater protection and viability time, 
facilitating a gradual release of rhizobacteria and causing a greater effect on growth and productivity in plants (Bashan et al., 2014; He et al., 2016; Schoebitz and Belchí, 2016).

\section{Conclusions}

Further work is necessary to perform assays in field to determine the potential of applying alginate microcapsules with $P$. putida as biofertilizer on promoting growth and productivity of tomato plants. Moreover, supplementary studies should be performed to determine their antagonic capacity toward phytopathogens, production of other hormones, such as gibberellins and cytokinins, nitrogen fixation, phosphorous solubilization, enzymatic activity (glucanases and chytinases), cyanhydric acid production, and siderophore synthesis. The use of PGPR as biofertilizers through alginate microcapsules can be a viable alternative in agronomic management of tomato plants and sustainable agricultural production.

\section{Acknowledgements}

The authors are thankful for financial and technical support provided by the Faculty of Agricultural Sciences Campus Xalapa, Universidad Veracruzana and D. Fischer for translation and editorial services.

\section{References}

Ahirwar, N.K., Gupta, G., Singh, V., Rawlley, R.K., Ramana, S. 2015. Influence on growth and fruit yield of tomato (Lycopersicon esculentum Mill.) plants by inoculation with Pseudomonas fluorescence (SS5): Possible role of plant growth promotion. Int. J. Curr. Microbiol. App. Sci. 4, 720-730.
Arseneault, T., Goyer, C., Filion, M. 2015. Pseudomonas fluorescens LBUM223 increases potato yield and reduces common scab symptoms in the field. Phytopathology. 105, 1311-1317.

Atieno, M., Herrmann, L., Okalebo, R., Lesueur, D. 2012. Efficiency of different formulations of Bradyrhizobium japonicum and effect of co-inoculation of Bacillus subtilis with two different strains of Bradyrhizobium japonicum. World J. Microbiol. Biotechnol. 28, 2541-2550.

Barea, J.M. 2015. Future challenges and perspectives for applying microbial biotechnology in sustainable agriculture based on a better understanding of plant-microbiome interactions. J. Soil Sci. Plant Nutr. 15, 261-282.

Bakker, P.A.H.M., Doornbos, R.F., Zamioudis, C., Berendsen, R.L., Pieterse, C.M.J. 2013. Induced systemic resistance and the rhizosphere microbiome. Plant Pathol. J. 29, 136-143.

Bashan, Y., de-Bashan, L.E., Prabhu, S.R., Hernandez, J.P. 2014. Advances in plant growth-promoting bacterial inoculant technology: formulations and practical perspectives (1998-2013). Plant Soil. 378, 1-33.

Belimov, A.A., Dodd, I.C., Safronova, V.I., Shaposhnikov, A.I., Azarova, T.S., Makarova, N.M., Davies, W.J., Tikhonovich, I.A. 2015. Rhizobacteria that produce auxins and contain 1-amino-cyclopropane-1-carboxylic acid deaminase decrease amino acid concentrations in the rhizosphere and improve growth and yield of well-watered and water-limited potato (Solanum tuberosum). Ann. Appl. Biol. 167, 11-25.

Berg, G. 2009. Plant-microbe interactions promoting plant growth and health: perspectives for controlled use of microorganisms in agriculture. Appl. Microbiol. Biotechnol. 84, 11-18. 
Gamalero, E., Martinotti, M.G., Trotta, A., Lemanceau, P., Berta, G. 2002. Morphogenetic modifications induced by Pseudomonas fluorescens A6RI and Glomus mosseae BEG12 in the root system of tomato differ according to plant growth conditions. New Phytologist. 155, 293-300.

Gamalero, E., Glick, B.R. 2015. Bacterial modulation of plant ethylene levels. Plant Physiol. 169, 13-22.

Glickmann, E., Dessaux, Y. 1995. A critical examination of the specificity of the Salkowski reagent for indolic compounds produced by phytopathogenic bacteria. Appl. Environ. Microbiol. 61, 793-796.

Gupta, G., Parihar, S.S., Ahirwar, N.K., Snehi, S.K., Singh, V. 2015. Plant growth promoting rhizobacteria (PGPR): current and future prospects for development of sustainable agriculture. J. Microb. Biochem. Technol. 7, 96-102.

He, Y., Wu, Z., Ye, B.C., Wang, J., Guan, X., Zhang, J. 2016. Viability evaluation of alginate-encapsulated Pseudomonas putida Rs-198 under simulated salt-stress conditions and its effect on cotton growth. Eur. J. Soil Biol. 75, 135-141.

Holguin, G., Bashan, Y. 1996. Nitrogen-fixation by Azospirillum brasilense $\mathrm{Cd}$ is promoted when cocultured with a mangrove rhizosphere bacterium (Staphylococcus sp.). Soil Biol. Biochem. 28, 1651-1660.

Hungria, M., Campo, R.J., Souza, E.M., Pedrosa, F.O. 2010. Inoculation with selected strains of Azospirillum brasilense and A. lipoferum improves yields of maize and wheat in Brazil. Plant Soil. $331,413-425$.

Israr, D., Mustafa, G., Khan, K.S., Shahzad, M., Ahmad, N., Masood, S. 2016. Interactive effects of phosphorus and Pseudomonas putida on chickpea (Cicer arietinum L.) growth, nutrient uptake, antioxidant enzymes and organic acids exudation. Plant Physiol. Biochem. 108, 304-312.
Joshi, B.H., Joshi, P.P. 2017. Screening and Characterization of Multi-Trait Plant Growth Promoting Bacteria Associated with Sugarcane for Their Prospects as Bioinoculants. Int. J. Curr. Microbiol. App. Sci. 6, 240-252.

Kamou, N.N., Karasali, H., Menexes, G., Kasiotis, K.M., Bon, M.C., Papadakis, E.N., Tzelepis, G.D., Lotos, L., Lagopodi, A.L. 2015. Isolation screening and characterization of local beneficial rhizobacteria based upon their ability to suppress the growth of Fusarium oxysporum f. sp. radicislycopersici and tomato foot and root rot. Biocontrol Science and Technology. 25, 928-949.

Kloepper, J.W. 1993. Plant-growth-promoting rhizobacteria as biological control agents. In: Metting E.B. (ed). Soil Microbial Ecology: applications in agricultural and environmental management. Marcel Dekker Inc., New York, pp: 255-273.

Lugtenberg, B., Kamilova, F. 2009. Plant-GrowthPromoting Rhizobacteria. Annu. Rev. Microbiol. 63, 541-556.

Mwita, L., Chan, W.Y., Pretorius, T., Lyantagaye, S.L., Lapa, S.V., Avdeeva, L.V., Reva, O.N. 2016. Gene expression regulation in the plant growth promoting Bacillus atrophaeus UCMB-5137 stimulated by maize root exudates. Gene. 590, 18-28.

Nadeem, S.M., Ahmad, M., Naveed, M., Imran, M., Zahir, Z.A., Crowley, D.E. 2016. Relationship between in vitro characterization and comparative efficacy of plant growth-promoting rhizobacteria for improving cucumber salt tolerance. Arch. Microbiol. 198, 379-387.

Ordookhani, K., Zare, M. 2011. Effect of Pseudomonas, Azotobacter and Arbuscular mycorrhizal fungi on lycopene, antioxidant activity and total soluble solid in tomato (Lycopersicon esculentum F1 Hybrid, Delba). Advances in Environmental Biology. 5, 1290-1294. 
Pastor, N., Masciarelli, O., Fischer, S., Luna, V., Rovera, M. 2016. Potential of Pseudomonas putida PCI2 for the protection of tomato plants against fungal pathogens. Curr. Microbiol. 73, 346-353.

Pathak, D., Lone, R., Koul, K.K. 2017. Arbuscular Mycorrhizal Fungi (AMF) and Plant GrowthPromoting Rhizobacteria (PGPR) Association in Potato (Solanum tuberosum L.): A Brief Review. In: Kumar, V., Kumar, M., Sharma, S., Prasad, R. (eds). Probiotics and Plant Health. Springer. Singapore, pp: 401-420.

Raaijmakers, J.M., Paulitz, T.C., Steinberg, C., Alabouvette, C., Moënne-Loccoz, Y. 2009. The rhizosphere: a playground and battlefield for soilborne pathogens and beneficial microorganisms. Plant Soil. 321, 341-361.

Schoebitz, M., Belchí, M.D.L. 2016. Encapsulation techniques for plant growth-promoting rhizobacteria. In: Arora, N.K, Mehnaz, S., Balestrini, R. (eds.). Bioformulations: for sustainable agriculture, First Edition. Springer India, pp: 251-265.

Shah, D.A., Sen, S., Shalini, A., Ghosh, D., Grover, M., Mohapatra, S. 2017. An auxin secreting Pseudomonas putida rhizobacterial strain that negatively impacts water-stress tolerance in Arabidopsis thaliana. Rhizosphere. 3, 16-19.

Shen, J., Li, C., Mi, G., Li, L., Yuan, L., Jiang, R., Zhang, F. 2013. Maximizing root/rhizosphere efficiency to improve crop productivity and nutrient use efficiency in intensive agriculture of China. J. Exp. Bot. 64, 1181-1192.

Sivakumar, P.K., Parthasarthi, R., Lakshmipriya, V.P. 2014. Encapsulation of plant growth-promoting inoculant in bacterial alginate beads enriched with humid acid. Int. J. Curr. Microbiol. App. Sci. 3 415-422
Solanki, M.K., Singh, R.K., Srivastava, S., Kumar, S., Kashyap, P.L., Srivastava, A.K., Arora, D.K. 2014. Isolation and characterization of siderophore producing antagonistic rhizobacteria against Rhizoctonia solani. J. Basic Microbiol. 54, 585-597.

Ul Hassan, T., Bano, A. 2015. The stimulatory effects of L-tryptophan and plant growth promoting rhizobacteria (PGPR) on soil health and physiology of wheat. J. Soil Sci. Plant Nutr. 15, 190-201.

Vacheron, J., Desbrosses, G., Bouffaud, M.L., Touraine, B., Moenne-Loccoz, Y., Muller, D., Legendre, L., Wisniewski-Dye, F., Prigent-Combaret, C. 2013. Plant growth-promoting rhizobacteria and root system functioning. Front. Plant. Sci. 4, 1-19.

Vázquez-Ovando, J.A., Andrino-López, D.K., Adriano-Anaya, M.L., Salvador-Figueroa, M., OvandoMedina, I. 2012. Sensory and physico-chemical quality of banana fruits "Grand Naine" grown with biofertilizers. African Journal of Agricultural Research. 7, 4620-4626.

Vejan, P., Abdullah, R., Khadiran, T., Ismail, S., Nasrulhaq Boyce, A. 2016. Role of plant growth promoting rhizobacteria in agricultural sustainability A review. Molecules. 21, 1-17.

Viscardi, S., Ventorino, V., Duran, P., Maggio, A., De Pascale, S., Mora, M.L., Pepe, O. 2016. Assessment of plant growth promoting activities and abiotic stress tolerance of Azotobacter chroococcum strains for a potential use in sustainable agriculture. J. Soil Sci. Plant Nutr. 16, 848-863.

Zerrouk, I. Z., Benchabane, M., Khelifi, L., Yokawa, K., Ludwig-Müller, J., Baluska, F. 2016. A Pseudomonas strain isolated from date-palm rhizospheres improves root growth and promotes root formation in maize exposed to salt and aluminum stress. J. Plant Physiol. 191, 111-119. 